\title{
Effect of Feeding Gliricidia sepium Leaves from Silvipasture Model of Agroforestry in Degraded Wastelands on Milk Yield and Its Composition in Milch Cows
}

\author{
S. Gunasekaran ${ }^{1 *}$, C. Bandeswaran ${ }^{1}$, C. Valli ${ }^{1}$ and H. Gopi ${ }^{2}$ \\ ${ }^{1}$ Institute of Animal Nutrition, Tamil Nadu Veterinary and Animal Sciences University, \\ Kattupakkam - 603 203, Tamil Nadu, India \\ ${ }^{2}$ Post Graduate Research Institute in Animal Sciences, TANUVAS, Kattupakkam - 603203, \\ Tamil Nadu, India \\ *Corresponding author
}

\section{A B S T R A C T}

\begin{tabular}{|l|}
\hline K e y w or d s \\
Gliricidia sepium, \\
$\begin{array}{l}\text { Milch cows, } \\
\text { silvipasture } \\
\text { Silvipasture model. }\end{array}$ \\
\hline Article Info \\
\hline $\begin{array}{l}\text { Accepted: } \\
\text { 21 September } 2017 \\
\text { Available Online: } \\
10 \text { October } 2017\end{array}$ \\
\hline
\end{tabular}

A lactation trial was conducted in crossbred (Jersey x Sindhi) milch cows for 60 days to study the effect of feeding Gliricidia sepium leaves from silvipasture model on the milk yield and its composition. The edible fresh fodder biomass yield from Gliricidia sepium (4 harvests / year) was $8.33 \mathrm{~kg} /$ tree. Fourteen mid-lactating dairy cows with an average body weight of $344.0 \mathrm{~kg}$ were randomly divided into two groups of seven each. In group I, Bajra -Napier hybrid grass $(5.16 \mathrm{~kg}$ on dry matter basis) constitute the roughage part of the ration, in group II, wilted Gliricidia sepium leaves ( 0.70 on dry matter basis) was offered as partial replacement of green grass. The average dry matter intake in group I and II animals was 7.41 and $7.30 \mathrm{~kg}$, respectively. The average daily milk yield (6.72 and 6.90 $\mathrm{kg}$ ), milk fat (4.31 and $4.285 \%$ ) solid non-fat $(8.10$ and $8.02 \%)$, milk protein (3.09 and $3.13 \%)$ and lactose $(4.20 \pm 0.06$ and $4.15 \pm 0.08 \%)$ in group I and group II were not altered significantly. Hence it is concluded that Gliricidia sepium can replace $15 \%$ of green fodder in lactating crossbred cows without affecting milk yield and its composition.

\section{Introduction}

Agroforestry considered as livelihood opportunities can integrate livestock with advantages in terms of improved soil fertility and animal production by reducing fodder scarcity. In agroforestry, fodder trees grown along with crops enhance fodder productivity and availability of fodder throughout the year. Trees contribute substantial amount of tree fodder (top feed), which can be used for feeding livestock through lopping at periodical intervals. Tropical tree legumes have the potential to produce large quantities of high protein leaves for animal consumption (Blom, 1980). This is particularly important in areas where the majority of ruminant animals are currently fed with forages and crop residues of low nutritive value (Preston and Murgueitio, 1992). It was reported that small ruminant farming based on silvipasture model is ideal and the average net income from rearing small ruminants in one ha of developed silvipasture is Rs.7868/- per year (Kareemulla, 2002). However, there is paucity of information on integrating milch 
cows with agroforestry systems. Hence, the present study was aimed at assessing the biomass yield of Gliricidia sepium in degraded wastelands of silvipasture model under rain fed conditions and also assessing the potential of integrating milch cows with Gliricidia sepium.

\section{Materials and Methods}

The experiment was conducted at Institute of Animal Nutrition, Tamil Nadu Veterinary and Animal Sciences University, Kattupakkam in cross bred (Jersey x Red Sindhi) milch cows for a period of 60 days. Fodders lopped from one hectare silvipasture model from ten year old Gliricidia sepium trees which was planted at a spacing of $2.5 \times 2.5 \mathrm{~m}$ with under storey of Stylosanthus scabra, a drought resistant perennial crop. The edible fresh fodder biomass yield from Gliricidia sepium (4 harvests / year) was calculated by pruning the tree fodder at periodical intervals. Soil nutrient status was analysed and the rainfall data was also recorded.

\section{Experimental animals and design of experiment}

Fourteen mid - lactating cross bred (Jersey $\mathrm{x}$ Sindhi) milch cows with an average body weight of $344.0 \pm 11.86 \mathrm{~kg}$ was selected and divided into two groups of seven each according to their body weight, age, parity and stage of lactation. The experimental animals were housed in well ventilated barns. All the animals were dewormed before the start of experiment for ecto and endo parasites.

In group I, Bajra -Napier hybrid grass (5.16 \pm $0.42 \mathrm{~kg}$ on dry matter basis) constituted the roughage part of the ration, whereas in group II, wilted Gliricidia sepium leaves (0.70 \pm $0.02 \mathrm{~kg}$ on dry matter basis) was offered as partial replacement of green grass after assessing the maximum intake. Gliricidia sepium was wilted for $6 \mathrm{hrs}$ in shade and offered to cows. All the cows were fed with concentrate mixture (digestible crude protein $14 \%$ and total digestible nutrients - $70 \%$ ) to satisfy $40 \%$ dry matter requirement. All the animals were individually fed and daily feed intake and its milk yield were recorded.

\section{Proximate analysis}

The proximate content of Gliricidia sepium, Bajra napier hybrid grass and concentrate feed were analyzed which constituted the ration in experimental animals. The samples were taken randomly and were analyzed (AOAC, 2000) for the dry matter (DM), crude protein $(\mathrm{CP})$, crude fibre $(\mathrm{CF})$, ether extract (EE) and total ash (TA).

\section{Milk composition analysis}

Milk samples were analysed chemically based on ISI standard methods. Milk fat, was analysed by Gerber method, Protein in the milk samples was estimated by Kjeldahl's Method (ISI, 1980) and the Lactose was estimated by Fehling solution (ISI, 1981).

\section{Statistical analysis}

An independent student's t-test was performed to compare the mean values between different treatment groups.

\section{Results and Discussion}

\section{Biomass yield of Gliricidia sepium from silvipasture}

The edible fresh fodder biomass yield from Gliricidia sepium (4 harvests/year) from silvipasture model in degraded wastelands was $8.33 \pm 0.28 \mathrm{~kg} /$ tree $(2.49 \mathrm{~kg}$ in terms of dry matter). An average rainfall of $1168 \mathrm{~mm}$ and the mean maximum and minimum temperature of $33.5^{\circ} \mathrm{C}$ and $25.4^{\circ} \mathrm{C}$ were recorded during the study period. 
Gliricidia sepium leaves had also high feeding value, with crude protein comprising $20-30 \%$ of the dry matter, a crude fibre content of only about $15 \%$, and in vitro dry matter digestibility of 60-65\% (Göhl, 1981; Adejumo and Ademosun, 1985) (Table 1).

\section{Milk yield and its composition}

The average dry matter intake in group I and II animals were found to be $7.41 \pm 2.67$ and $7.30 \pm$
$3.15 \mathrm{~kg}$, respectively. The average daily milk yield $(6.72$ and $6.90 \mathrm{~kg})$, milk fat (4.31 and 4.28 $\%)$ solid not fat (8.10 and $8.02 \%)$, milk protein (3.09 and $3.13 \%)$ and lactose (4.20 and $4.15 \%)$ in group I and II were not affected significantly due to dietary treatments.

The higher protein content of Gliricidia sepium leaves resulted in the marginal increase of milk yield (180 g/day) (Table 2 ).

Table.1 Proximate composition of feed resources

\begin{tabular}{|l|c|c|c|}
\hline \multicolumn{1}{|c|}{ Nutrients } & Gliricidia sepium & Bajra napier hybrid grass & Concentrate feed \\
\hline Crude protein & $17.85 \pm 0.19$ & $7.92 \pm 0.08$ & $16.01 \pm 0.82$ \\
\hline Crude fibre & $19.24 \pm 0.67$ & $37.24 \pm 0.85$ & $8.42 \pm 0.41$ \\
\hline Ether extract & $3.98 \pm 0.14$ & $2.10 \pm 0.10$ & $2.75 \pm 0.15$ \\
\hline Total ash & $8.96 \pm 0.49$ & $11.15 \pm 0.31$ & $7.21 \pm 0.07$ \\
\hline Nitrogen free extract & $49.96 \pm 1.11$ & $41.57 \pm 0.56$ & $65.59 \pm 1.46$ \\
\hline
\end{tabular}

Table.2 Effect of Gliricidia sepium on milk yield and its composition in milch cows

\begin{tabular}{|l|c|c|}
\hline Parameters* & Group-I & Group-II \\
\hline Average milk yield (kg/day) & $6.72 \pm 0.49$ & $6.90 \pm 0.34$ \\
\hline Dry matter intake (kg/day) & $7.41 \pm 2.67$ & $7.30 \pm 3.15$ \\
\hline Fat $(\%)$ & $4.31 \pm 0.30$ & $4.28 \pm 0.35$ \\
\hline Solid not fat (\%) & $8.10 \pm 0.75$ & $8.02 \pm 0.71$ \\
\hline Protein (\%) & $3.09 \pm 0.25$ & $3.13 \pm 0.16$ \\
\hline Lactose (\%) & $4.20 \pm 0.06$ & $4.15 \pm 0.08$ \\
\hline
\end{tabular}

*Non-significant

Biomass yield of Gliricidia sepium from silvipasture

Nitis (1991) reported that Gliricidia sepium planted as fencing (0.1 $\mathrm{m}$ spacing), alley cropping (0.5 m spacing) and as guardrows (1.0 $\mathrm{m}$ spacing) and harvested four times a year, produced $0.20,1.48$ and 1.94 kilograms of DM each tree per year, respectively. Soil nutrient status of silvipasture for $\mathrm{N}$ (kg/acre), $\mathrm{P}$ (kg/acre), $\mathrm{K}$ (kg/acre), EC, $\mathrm{pH}$ and Soil texture was $87.67 \pm 12.69, \quad 3.33 \pm 0.33,117.00 \pm 15.52$, $0.13 \pm 0.03,6.87 \pm 0.37$ and sandy loam, respectively. Kareemulla (2002) reported that degraded lands can be effectively used for producing forage, nutritious leaf fodder, fuel wood and timber with the introduction of silvopastoral system based on species like Albizia amara, Leucaena leucocephala, Dichrostachys cinerea (tree component); Chrysopogan fulvus, Stylosanthes hamata and S. scabra (pasture component) and also recorded the biomass productivity of $7.13 \mathrm{t} \mathrm{ha}^{-1}$ year $^{-1}$

\section{Milk yield and its composition}

According to Preston and Leng (1987), the growth rate of steers in Colombia fed on King grass supplemented with Gliricidia increased curvilinearly with supplementation level and highest growth rate was at about 30\% Gliricidia. Chadhokar and Lecamwasam (1982) and Premaratne (1990) showed increase in live 
weight gain for milking cows and buffalo on low protein diets supplemented with Gliricidia, although supplementation levels over $50 \%$ were reported to cause tainting of the milk. Kabaija and Smith (1989) concluded that Gliricidia sepium could also be a good source of minerals if fed as sole feed, except for $\mathrm{Cu}$ and $\mathrm{P}$ which are need to be supplemented. However, the use of pure Gliricidia leaves is unusual, even during the dry season. Hence, it was concluded that Gliricidia sepium harvested from silvipasture system can replace $15 \%$ of green fodder in lactating crossbred cows with marginal increase in milk yield and can hold 14 cows per year per hectare without any adverse effect on its milk yield and composition.

\section{Acknowledgement}

The authors are grateful to Director, Central Agroforestry Research Institute, Jhansi as this work was conducted under ICAR - AICRP on Agroforestry.

\section{References}

A.O.A.C. 2000. Official methods of Analysis, Association of Official Analytical Chemists. International volume I, $17^{\text {th }}$ edition, Gaithersburg, Maryland, USA.

Adejumo, J.O., and. Ademosun, A.A. 1985. Effect of plant age at harvest and of cutting time frequency and height on the dry matter yield and nutritive value of Gliricidia sepium and Cajanus cajan. Journal of Animal Production Research 5, 1-12.

Chadhokar, P.A., and Lecamwasam, A. 1982. Effect of feeding Gliricidia maculata to milking cows a preliminary report. Tropical Grasslands 16, 4648.
Gohl, B., 1981. Tropical feeds; feed information summaries and nutritive values. FAO Animal Production and Health Series, No. 12. FAO, Rome, Italy, $529 \mathrm{pp}$.

ISI Handbook of Food Analysis, Part-11, 1981. ISI Handbook of food analysis, Part-I, 1980.

Kabaija, E., and Smith, O.B 1989. Influence of season and age of regrowth on the mineral profile of Gliricidia sepium and Leucaena leucocephala, Tropical Agriculture 66, 125-128.

Kareemulla, K., Rai, P., Rao, G.R., and Solanki, K.R., 2002. Economic analysis of silvipastoral system for degraded lands under rain fed conditions, Indian Forages, 128 (12): 1346-1450.

Nitis, I.M., Putra, S., Sukanten, W., Suarna, M. and Lana, K. 1991. Fitting forage into intensive plantation crop systems in Bali, ACIAR Workshop on forage for plantation crop. Denpasar, Indonesia. 23 pp.

Premaratne, S., 1990. Effect of non-protein nitrogen and fodder legumes on the intake, digestibility and growth parameters of buffaloes. In: Domestic Buffalo Production in Asia, Proceedings of the final research coordination meeting on the use of nuclear techniques to improve domestic buffalo production in Asia - phase II, Rockhampton, Australia. International Atomic Energy Agency, Vienna, Austria.

Preston, T.R., and Leng, R.A.1987. Matching Ruminant Production Systems with available Resources in the Tropics and Sub-tropics, Penambul Books, Armidale, Australia.

Preston, T.R., and Murgueitio E. 1992. Strategy for sustainable livestock production in the tropics, Condrit Ltda: Cali pp89.

\section{How to cite this article:}

Gunasekaran, S., C. Bandeswaran, C. Valli and Gopi, H. 2017. Effect of Feeding Gliricidia sepium Leaves from Silvipasture Model of Agroforestry in Degraded Wastelands on Milk Yield and Its Composition in Milch Cows. Int.J.Curr.Microbiol.App.Sci. 6(10): 2420-2423. doi: https://doi.org/10.20546/ijemas.2017.610.285 